\title{
PENINGKATAN KUALITAS PELAYANAN PDAM DALAM MEWUJUDKAN SMART LIVING
}

\section{IMPROVING THE QUALITY OF PDAM SERVICES IN REALIZING SMART LIVING}

\author{
Kristina Setyowati, Priyanto Susiloadi, Retno Suryawati \\ Fakultas Ilmu Sosial dan Politik Universitas Sebelas Maret \\ Kristina@staff.uns.ac.id
}

\begin{abstract}
Abstrak
Smart City dalam kehidupan masyarakat diharapkan dapat meningkatakan pelayanan publik. Salah satu kriteria dalam Smart City adalah Smart Living yang berarti suatu ide atau gagasan mengenai bagaimana menciptakan kondisi interior / lingkungan menjadi lebih efisien, lebih aman, lebih sehat dan estetis. Untuk mewujudkan Smart Living, maka dilakukan dengan cara peningkatan kualitas pelayanan PDAM. Tujuan penelitian ini untuk meningkatkan kualitas pelayanan PDAM, sehingga tersedianya pelayanan air bersih yang sehat. Metode yang diginakan dengan metode diskriptif kuantitatif, dengan menggunakan skala Likert. Untuk mengukur kualitas pelayanan dilakukan dengan melihat gap antara persepsi pelanggan atas kepentingan (harapan) dengan kinerja pelayanan yang diterima, yang dilihat dari dimensi menurut Parasuraman yang meliputi dimensi : RATER : Reliability, Assurance, Tangible, dan Empati dan Responsiveness. Hasil penelitian disimpulkan bahwa kulaitas pelayanan PDAM belum bisa mewujudkan Smart Living, karena masih ada 7 kriteria di kuadran A, yaitu : a) jaminan ketersediaan air bersih dan jernih, b) jaminan higenis air, c) jaminan debit air yang banyak, d) kontunitas air lancar, e) jaminan adanya kontrol terhadap saluran air secara berkala , f) kriteria ketepatan dalam mencatat meteran, g) kriteria kepekaan pegawai dalam merespon segala kebutuhan dan keluhan pelanggan yang merupakan kriteria yang sangat mendukung Smart Living. Rekomendasi yang diberikan hendaknya sangat memprioritaskan semua kriteria yang berada di kuadran A untuk lebih ditingkatkan kinerjanya
\end{abstract}

\section{Kata kunci : PDAM, kualitas pelayanan , smart living}

\begin{abstract}
Abstrack
Smart City in people's lives is expected to improve public services. One of the criteria in Smart City is Smart Living. which means an idea or idea about how to create interior / environmental conditions becomes more efficient, safer, healthier and aesthetically pleasing. To realize Smart Living, it is done by increasing the quality of PDAM services. The purpose of this study is to improve the quality of
\end{abstract}


PDAM services, so that the availability of healthy clean water services. The method used by descriptive quantitative method, using a Likert scale. To measure Service Quality is done by looking at the gap between customer perceptions of interests (expectations) with the service performance received, which is seen from the dimensions according to Parasuraman which includes dimensions: RATER: Reliability, Assurance, Tangible, and Empathy and Responsivness. The results of the study concluded that the service quality of PDAMs could not realize Smart Living, because there are still 7 criteria in quadrant A, namely: a) Guaranteed availability of clean and clear water, b) Water hygiene guarantee, c) guarantee of large water discharge, d) Contention smooth water, e) Guarantee of control of waterways on a regular basis, f) criteria for accuracy in recording meters, g) employee sensitivity criteria in response to all customer needs and complaints) which is a criteria that strongly supports Smart Living. The recommendations given should prioritize all criteria in the A quadrant to improve their performance

\section{Keywords: PDAM , service quality, smart living,}

\section{A. Pendahuluan}

Ketika kompleksitas permasalahan kota muncul, maka pemerintah harus melakukan langkah improvisasi dalam pelayanan publik, dengan pendekatan yang bersifat komprenhensif dan integratif yaitu suatu pendekatan yang mampu mengakomodir seluruh permasalahan kota. Sebagaimana menurut Poernomo (2015) : "untuk mengatasi persoalan kota yang semakin kompleks, menuju kota masa depan yang diimpikan oleh penduduknya, yang dikenal dengan sebutan konsep Smart City atau kota "cerdas" atau kota "impian masa depan".

Untuk mewujudkan pembangunan kota yang berkelanjutan yang inovatif, melalui peningkatan kualitas pelayanan publik, dalam mencapai keunggulan kompetitif, maka " Smart City “ (Kota Cerdas) dianggap sebagai sebuah strategi untuk meningkatkan kualitas hidup di ruang perkotaan, yang mencakup peningkatkan kualitas lingkungan maupun kualitas pelayanan publik.

Konsep Smart City mempunyai beberapa elemenan menurut ( 7) antara lain : yaitu Smart Economy, (ekonomi yang pintar), Smart People (masyarakat yang pintar) Smart Governance (pemerintahan yang pintar) Smart Environment (lingkungan yang pintar), Smart Living (pola hidup yang pintar), Smart Mobility (pergerakan yang pintar). Pemahaman bahwa pelayanan akan lebih baik jika terpusat pada masyarakat; infrastruktur fisik yang cerdas; serta pola hidup yang cedas /pintar. Konsep Sehat dalam Smart Living, dalam arti bagaimana lingkungan 
tempat tinggal (fentilasi, penyinaran udara, kebersihan, kualitas air, sanitasi, drainase) itu memadai. Untuk bisa mewujudkan Smart Living (Kehidupan cerdas /pintar) khususnya pada dimensi Sehat Lingkungan maka harus ada upaya dari pemerintah untuk mendukungnya.

Salah satu terpenuhinya Sehat Lingkungan adalah tersedianya air bersih. Kebutuhan air bersih yang layak dan aman dikonsumsi setiap hari nampaknya terus meningkat. Akan tetapi masih ada beberapa permasalahan air bersih di Perkotaan, antara lain: debit air yang tidak stabil (sering mati, air berbau , air keruh dan sebagainya). Selain kondisi airnya, seringkali masalah pelayanan yang diberikan oleh Perusahaan Daerah Air Minum (PDAM) adalah pihak yang menyediakan kecukupan air bersih kurang begitu responsif terhadap keluhan pelanggan.

Penelitian ini dilakukan di PDAM Kabupaten Karanganyar, melakukan langkah improvisasi dengan diberlakukannya Peraturan Daerah Kabupaten Karanganyar Nomor 5 Tahun 1983 tentang Perusahaan Daerah Air Minum, dan telah disempurnakan terakhir dengan Peraturan Daerah Kabupaten Karanganyar Nomor 13 Tahun 2007 tentang Perusahaan Daerah Air Minum Kabupaten Karanganyar, dengan membentuk PDAM Tirta Lawu.

Beberapa permasalahan yang dihadapai PDAM Tirta Lawu Karanganyar, berdasarkan dari hasil evaluasi yang dilakukan, ada indikasi kehilangan air di PDAM Tirta Lawu lebih dari 40 persen. Sehingga aliran air yang sampai di pelanggan tidak dapat optimal, masih banyaknya meter air pelanggan, hingga jaringan distribusi yang berpotensi bocor, debit air yang kecil dan masih rendahnya penguasaan dasar ilmu bidang air minum bagi karyawan PDAM menyebabkan mereka sulit menangani permasalahan aliran di pipa distribusi," ujar Direktur Utama PDAM Tirta Lawu. Prihanto,S.E.,M.M (dalam http://perpamsi.or.id).

Berdasarkan fenomena di atas, maka perlu dikaji secara lebih mendalam bagaimana meningkatkan kualitas pelayanan PDAM. Peningkatan kualitas pelayanan PDAM diharapkan dapat meningkatan kesehatan lingkungan, yang merupakan dimensi sehat pada Smart Living. Berdasarkan uraian di atas maka State of the Art dari penelitian ini adalah: "Peningkatkan derajat kesehatan lingkungan nasyarakat yang dilakukan melalui peningkatan kualitas pelayanan publik PDAM, diharapkan bisa terwujudnya Smart Living”. 
"Konsep smart

living intinya

merupakan konsep tempat tinggal yang tak hanya berpusat pada estetika, namun juga kondisi sang pemilik dan lingkungan sekitarnya," dengan kata lain Smart living merupakan cara pandang, pola pikir yang berujung pada paradigma kecermatan, praktis, dan kreatifitas. Salah satu aspek yang patut diperhatikan jika ingin memiliki hunian dengan konsep smartliving adalah adanya "Konsep Sehat". Kosep Sehat dalam Smart Living bisa meliputi Sehat hunian, kecukupan udara (ventilasi rumah) sehingga mampu penghematan listrik, kecukupan / ketersediaan air bersih yang sehat (dalam https://www.viva.co.id).

Beberapa kajian inovasi Smart Living antara lain kajian yang dilakukan Kurnaedi (2017) dengan judul "Penerapan LIVE Smart City Kota Tangerang" :

"menganalisa kekuatan dan kelemahan dari sistem informasi LIVE yang telah digunakan dengan menggunakan PIECES Framework, serta untuk menentukan apakah ada dampak dari tingkat keuntungan yang meningkat dalam penggunaan sistem agar perusahaan dapat melakukan tindak lanjut dari prospek bisnis untuk menghadapi berbagai tantangan global. Metode yang digunakan adalah metode analisis PIECES
Framework, yang terdiri dari beberapa poin analisa, yaitu Performance, Informations and Data, Economic Data, Economics, Control and Security, Efficiency, and Service".

Sementara kajian Hayati dkk (2017 ) yang berjudul From Smart Living into Smart City: A Lesson from Kampung of Surabaya " menyatakan :

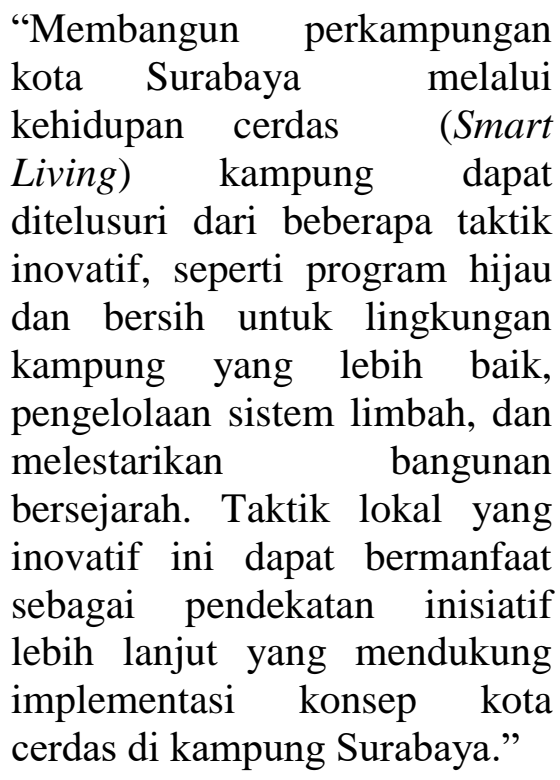

Kajian Hassan, Shehab dan Peppard ( 2010 ) dengan judul "Toward Full Public E-Services Environment in Developping Countris" yang pada initinya bagaimana merubah sistem birokrasi untuk lebih responsif terhadap perubahan dan tuntutan kebutuhan akan kemajuan tehnologi. Kajian ini bertujuan untuk menyajikan kerangka kerja akonceptual untuk menjelaskan hambatan manusia dan dalam 
pengembangan pegerakkan $e$-public service.

Pelayanan publik yang diberikan oleh organisasi publik yang berupa jasa pelayanan atau seringkali disebut dengan pelayanan birokrasi harus mampu memberikan pelayanan yang berkualitas, sehingga mampu mendorong aktivitas ekonomi dan menjadi center of excellence / pusat keunggulan pemerintahan. Kualitas layanan menjadi hak masyarakat yang harus dipenuhi oleh birokrasi. Sebagaimana ditegaskan oleh Sinambela (2006:43) bahwa "kualitas pelayanan birokrasi yaitu melayani konsumen sesuai dengan kebutuhan dan seleranya". Artinya segala sesuatu yang berkaitan dengan pelayanan semuanya sudah terukur ketepatannya, karena yang diberikan adalah kualitas.

Pengertian yang lain tentang kualitas Crosby (1979), Ducker,1991 (dalam Aykac, et.all :2009), dan Nasution (2004: 47) kualitas jasa adalah perbedaan antara yang diharapkan (expected service) dan layanan jasa yang diterima (perceved service). Jika jasa yang diterima melampaui harapan publik maka kualitas jasa yang dipersepsikan adalah kualitas baik, dan jika sebaliknya maka kualitasnya buruk". Sementara Upaya untuk mewujudkan pelayanan publik yang berkualitas, menurut Suprapto (1998:12) adalah :

\begin{abstract}
"bahwa kualitas pelayanan sangat menentukan sebuah sistem birokrasi yang responsif terhadap kebutuhan dan tuntutan masyarakat, sekaligus mencerminkan sebuah citra pemerintahan yang bersih, berwibawa dan efisien. Dengan kata lain membangun sistem birokrasi yang ditempatkan sebagai pelayan yang maksimal dalam langgam good governance sangat ditentukan oleh kualitas pelayanan yang diberikan".
\end{abstract}

Beberapa kajian tentang kualitas pelayanan, Felix (2017) dalam kajiannnya yang berjudul "Service Quality and Customer Satisfaction in Selected Banks in Rwanda, hasil temuan : "hubungan yang signifikan dan positif antara kualitas layanan dan kepuasan pelanggan". Kajian Yarimoglu (2014) yang berjudul "A Review on Dimensions of Service Quality Models" hasilnya reviewnya adalah : "adanya kaitan antara tiga elemen: lingkungan fisik, orang, dan proses dengan bauran pemasaran layanan, yaitu security, consistency, attitude, completeness, condition, availability, and training of service providers".

\section{B. Metode Penelitian}

Mengukur kualitas pelayanan dengan Metode SERVQUAL ini dikembangkan oleh Parasuraman, Zeithaml, dan Berry (1997: 219) yang dikenal dengan Gap Model Analysis, yang diukur melalui lima 
(5) dimensi, yang disebut RATER, yaitu : Reliability, Assurance, Tangibles, Empathy dan, Resposiveness. Jenis penelitian adalah penelitian deskriptif kuantitatif dengan metode survei dan jumlah responden sebanyak 40 pelanggan, metode analisis Importance and Performance Analysis (IPA) atau analisis tingkat kepentingan dan kinerja/kepuasan pelanggan, Selanjutnya kedua informasi atau variabel tersebut dianalisa dengan mengagunakan diagram kartesius .

\section{Hasil Dan Pembahasan}

Penelitian tentang peningkatan kualitas pelayanan PDAM dalam mewujudkan smart living di Kabupaten Karanganyar hasil kajian, untuk mengukur kualitas pelayanan PDAM melalui 5 dimensi, yaitu:

1. Dimensi Reliability mencakup : keterandalan tercakup : (a) kecepatan pegawai dalam administrasi /pelayanan di loket, (b) kecepatan pegawai dalam hal pasang baru, (c) ketepatan dalam mencatat meteran, (d) kemampuan pegawai menjalankan SOP.

2.Dimensi Responsiveness mencakup : (a) pegawai sigap dalam menangani keluhan pelanggan, (b) pegawai tanggap pada kebutuhan pelanggan, (c) pegawai tanggap dengan masalah pelanggan, (d) kepekaan pegawai dalam merespon segala kebutuhan dan keluhan pelanggan.

3. Dimensi Assurance mencakup p : (a) jaminan ketersediaan air bersih dan jernih,( b) jaminan higenis air, (c) jaminan debit air yang banyak, (d) kontunitas air lancar, ( e) jaminan adanya kontrol terhadap saluran air secara berkala.

4. Dimemsi Emphati mencakup : (a) pegawai sangat peduli dengan pelanggan, (b) pegawai sangat ramah, sopan dalam melayani pelanggan, (c) pegawai dengan sabar memberikan informasi yang dibutuhkan pelanggan.

5. Dimensi Tangible mencakup: (a) tersedianya tempat parkir yang luas, (b) tersedianya ruang tunggu yang besih dan nyaman, (c) tersedianya tempat antrian yang memadai, (d) tersedianya toilet yang bersih, (e) kelengkapan pelayanan administrasi, (f) kelengkapan fasilitas teknis

Dari hasil perhitungan metode Importance and Performance Analysis (IPA) atau analisis tingkat kepentingan dan kinerja/kepuasan pelanggan, Selanjutnya kedua informasi atau variabel tersebut dianalisa dengan mengagunakan diagram kartesius diperoleh perhitungan senagai berikut : 
Gambar 1

Diagram Kartesius Antara Harapan dan Kinerja Pelayanan PDAM

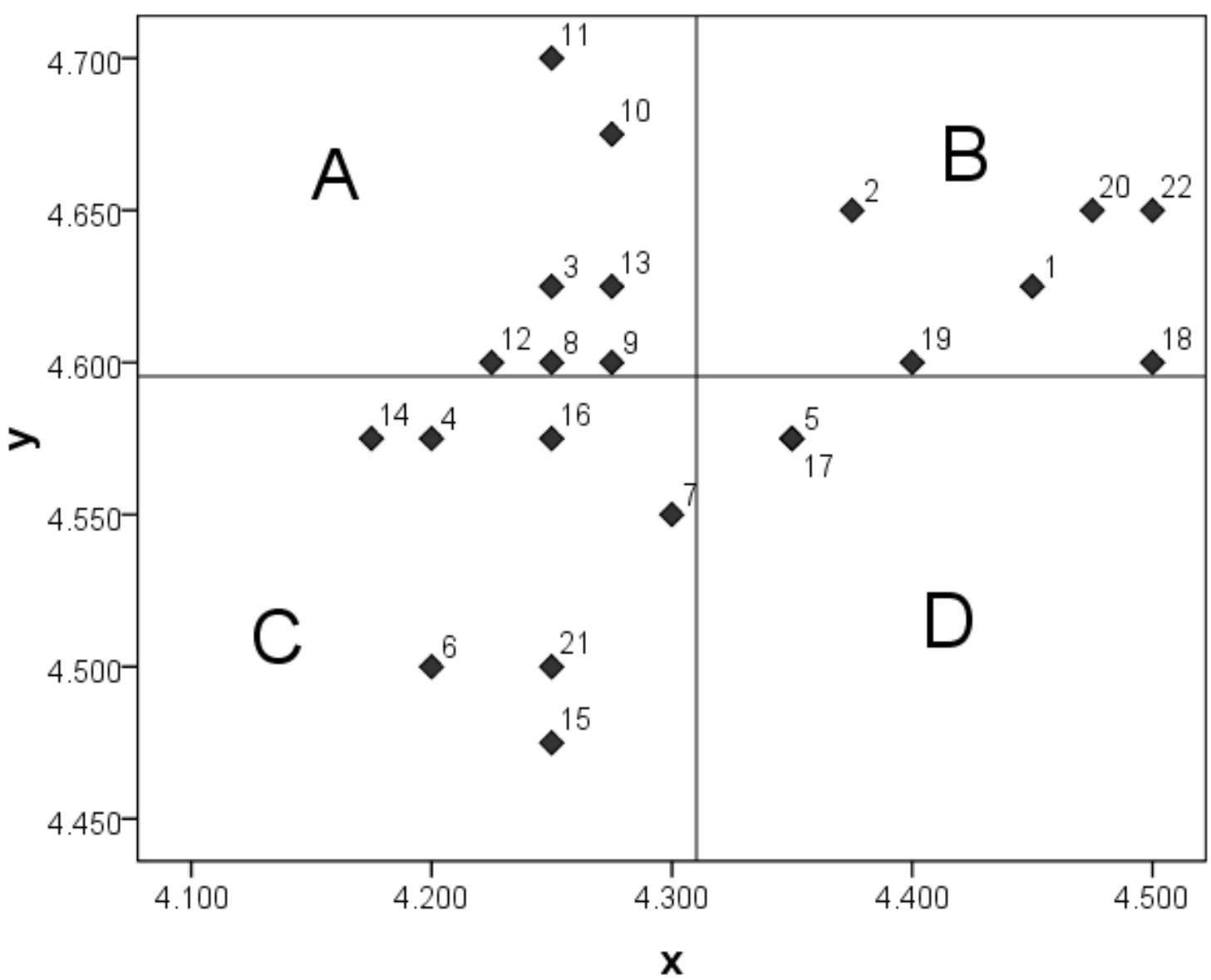

Sumber : Data diolah

Berdasarkan diagram kartesius, terdapat 7 kriteria /atribut pada kuadran A yaitu : kriteria (3) ketepatan dalam mencatat meteran, kriteria (8) kepekaan pegawai dalam merespon segala kebutuhan dan keluhan pelanggan, kriteria (9) jaminan ketersediaan air bersih dan jernih, kriteria (10) jaminan higenis air, kriteria (11) jaminan debit air banyak, kriteria (12) jaminan kontinuitas air lancar dan kriteria
(13) jaminan adanya kontrol terhadap saluran air secara berkala. Pada kuadran A merupakan (prioritas utama) disebut juga (attributes to improve) atribut-atribut yang berada pada kuadran ini yang menjadi prioritas utama untuk segera ditingkatkan kualitas pelayanannya.

Pada Kuadran B terdapat 6 kriteria, yaitu : kriteria (1) kecepatan pegawai dalam administrasi /pelayanan di 
loket, kriteria (2) kecepatan pegawai dalam hal pasang baru, kriteria (18) tersedianya ruang tunggu yang besih dan nyaman, kriteria (19) tersedianya tempat antrian yang memadai, kriteria (20) tersedianya toilet yang bersih, kriteria (22): kelengkapan fasilitas teknis. pada kuadran b (maintain performace), pada atribut ini perlu dipertahankan prestasinya.

Pada kuadran $\mathrm{C}$ terdapat 7 kriteria, yaitu kriteria (4) kemampuan pegawai menjalankan SOP, kriteria (6) pegawai tanggap pada kebutuhan pelanggan, kriteria (7) pegawai tanggap dengan masalah pelanggan, kriteria (14) pegawai sangat peduli dengan pelanggan, kriteria (15) pegawai sangat ramah, sopan dalam melayani pelanggan, kriteria (16) pegawai dengan sabar memberikan informasi yang dibutuhkan pelanggan, kriteria (21) kelengkapan pelayanan administrasi. pada kuadran C (attributes to maintain), ini merupakan atribut yang mempunyai prioritas rendah, artinya tidak perlu memprioritaskan atribut atribut ini, karena memang kurang diharapkan pengguna,

Pada kuadran D terdapat 2 kriteria, yaitu kriteria (5) pegawai sigap dalam menangani keluhan pelanggan, dan kriteria (17) tersedianya tempat parkir luas. Pada kuadran D (main to priority) merupakan atribut yang surplus, artinya kinerjanya sangat bagus akan tetapi bukan merupakan atribut yang diharapkan (tidak penting) bagi pengguna, sebaiknya dikurangi peningkatannya pada atribut ini, sehingga dapat menghemat biaya.

\section{Penutup}

Berdasarkan perhitungan dengan metode analisis Importance and Performance Analysis (IPA) atau Analisis Tingkat Kepentingan dan kinerja/kepuasan pelanggan, yang selanjutnya dianalisis dengan diagram kartesius maka dapat disimpulkan bahwa kualitas pelayanan PDAM belum bisa mewujudkan Smart Living, karena dari 22 kriteria yang dianalisiss ada 8 kriteria yang kinerjanya diatas ratarata (6 atribut berada di kuadran B, dan ada 2 atribut di kuadran D). Dua atribut yang berada di kuadran D ini merupakan atribut yang pemborosan karena atribut ini tadak begitu diharapkan pelanggan namum kinerjanya tinggi. Selain itu masih ada 7 atribut di kuadran A, dimana atribut atribut ini yang harus diprioritaskan karena atribut dikuadran A adalah atribut yang sangat diharapkan oleh pelanggan, namun kinerjanya rendah.
Rekomendasi yang diberikan hendaknya sangat memprioritaskan semua kriteria yang berada di kuadran A untuk lebih ditingkatkan kinerjanya. Sementara ada satu 
kriteria yang berada di kuadran D , perlu dikaji ulang supaya lebih efisien.

\section{Daftar Pustaka}

Aykac, Aydyn, Ates, Cetin, 2009, "Effects of Service Quality on Costomer Satisfaction and Customer Loyalty: Marmara University Hospital", International Congress on Performance and Quality in Health (Uluslararasi Saglikta Performans ve Kalite Kongresi), March 19-21, 2009, Antalya, Turkey (http://ssrn.com.abstract/ 1362601

Felix, Robogura (2017) Service Quality and Customer Satisfaction in Selected Banks in Rwanda. Journal of Business and Financial Affair 6: 246. doi: $\quad$ 10.4172/21670234.1000246

Hassan, Shehab, and J.Peppard, 2010, Toward Full Public E-Service Environment Developing Countries, International Journal of Economics and Management Enginering, Vol.4 No.6

Hayati , Karina, irami Bararatin1, Adinda S.P.R Utamil , Dewi Septanti1, Happy Ratna Santosa , Gabriele Weichart , Mag. Karl Valent (2013) , From Smart Living into Smart City: A Lesson from Kampung of Surabaya, UIA 2017 Seoul World Architects Congress https://www.viva.co.id/gayahidup/kuliner/441109-menilikempat-konsep-hunian-smartliving)

http://perpamsi.or.id/berita/view/201 6/12/15/303/pdam-karanganyartemukan-kebocoran-di-atas-40persen)

Lehtinen, U. and Lehtinen, J. R. (1982). Service quality: a study of quality dimensions. Helsinki: Service Management Institute, Unpublished working paper, Finland OY.

Parasuraman, Zeithaml and Berry, 1997, “A Conceptual Model of Services Quality and Its Implications for Future Reseach, Journal of Marketing , Vol.49. Autumn( 1997:219).

Parasuraman, A., Zeithaml, V. A. and Berry, L. L. (1988). SERVQUAL: a multiple-item scale for measuring consumer perceptions of service quality. Journal of Retailing. 64 (1): $12-40$

Poernomo, Djoko. 2015, “ Manajemen Strategis Smart City", Seminar Nasional Riset Terapan 2015 | Senasset 2015, Https://Www.Researchgate.Net/P ublication/287743913

Nasution, M.N., 2004, Manajemen Mutu Terpadu, Ghalia Indonesia, Jakarta.

Sinambela, Lijan, Poltak, 2008, Reformasi Pelayanan Publik : Teori, Kebijakan dan 
Implementasi, Penerbit : Bumi

Aksara, Jakarta.

Suprapto, Riyadi, 1998, "Clean

Goverment.Kinerja Birokrasi

dan Pelayanan Publik : Telaah

Kritus", Orasi Ilmiah Dalam

Wisuda Sarjana Sarjana STIA

Muhamadiyah Selong-Lombok

Timur, 6Mei 1998.

Yarimoglu, Emel Kursuluoglu, 2014,

"A Review On Dimensions of Service Quality Model",

Journal of Marketing

Managemen Vol.2 No.2 Pp 79-

93 , June 2014 